\title{
二重倒立振子の任意平衡点への知的安定化制御*
}

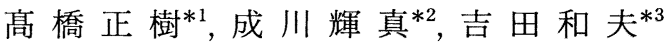

\section{Intelligent Stabilization Control to Arbitrary Equilibrium Point of Double Inverted Pendulum}

\author{
Masaki TAKAHASHI*4, Terumasa NARUKAWA and Kazuo YOSHIDA \\ ${ }^{* 4}$ School of Science for Open and Environmental Systems, Keio University, \\ 3-14-1 Hiyoshi, Kohoku-ku, Yokohama-shi, Kanagawa, 223-8522 Japan
}

\begin{abstract}
This study aims at establishing a robust and effective intelligent control method for nonlinear and complicated systems by extending the integrated Cubic Neural Network (CNN). In the method, an integrator neural network acquires optimum switching and integration of several controllers for a different local purpose by calculating the fitness based on the system object using the genetic algorithm. The proposed method is applied to an equilibrium point transfer and stabilization control of a double pendulum that possesses four equilibrium points, namely Down-Down, Down-Up, UpDown and Up-Up points. In order to verify the effectiveness of the proposed method, simulations and experiments were carried out. As a result, it was demonstrated that the integrated intelligent controllers can transfer and stabilize the double pendulum from the arbitrary equilibrium points to arbitrary one without touching the cart position limit. In addition, by taking account of energy variation, the double pendulum was transferred from Up-Down to Up-Up and was stabilized without falling down.
\end{abstract}

Key Words: Intelligent Control, Nonlinear Control, Double Pendulum, Cubic Neural Network, Genetic Algorithm

\section{1. はじめに}

制御技術が適用されるシステムは複雑化・非線形化 しており，そのようなシステムに対して十分な制御性 能を持つ制御手法の確立が望まれている. しかし, シス テムの特性の複雑さに加えて, 環境の変化, 多様な制約 など多数の要素が組み合わさることによって生じる複 雑さによって，その制御系設計は容易ではない，また， そのようなシステムに要求される制御の多様化や高度 化に伴い, システム内に解決するべき問題が複数存在 している場合が多くなっている，そのような場合には, 各制御問題に対して，いくつかの制御則や切換え則が 必要となり，すべての制御問題を解決するためには, シ ステム内に多数の制御則や切換え則が混在することに なる。それらの理論的かつ明示的な条件による最適な 切換え条件の導出は困難であり, 十分な制御性能が得 られない場合がある．著者の一人は，そのような問題に

* 原稿受付 2003 年. 3 月 19 H

*1 正員, 慶應義塾大学大学院理工学研究科(画223-8522 横浜 市港北区日吉 3-14-1).

*2 学生員, 穈礁義塾大学理工学部。

*3 正貪, フェロー, 慶應義塾大学理工学部.

E-mail : masaki55@2000.jukuin.keio.ac.jp
対して, 従来の制御理論のみでは対応できない問題を 解決する一つの方法として, 学習や適応などの特徵を 有する知的制御に注目し，キュービックニューラル ネットワーク(Cubic Neural Network：CNN)知的制御手 法を提案している(1).これまでに，知的制御を相補う形 で制御系に融合することで, 従来の制御理論では困難 であった様々な効果が確認されている(2)．また，ひとつ の典型的な非線形制御問題の例題として, 単振子の振 上げ・倒立制御(3)，二重振子の振上げ・倒立制御(4)(S)の 問題に応用し，定性的な制御の導入と力学法則の埋め 込みを特徵とする図 1 に示す統合化 CNN 知的制御手法

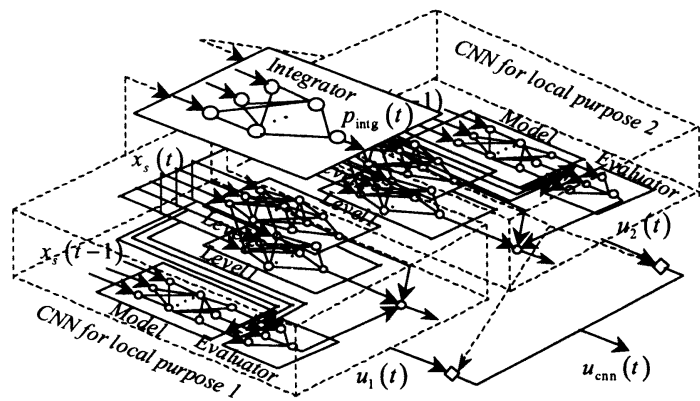

Fig.1 Integrated Cubic Neural Network. 
を確立している. ニューロ型非線形切換え超平面を有 する統合器を設計し, 目的の異なる複数の線形制御器 に対して並列に配置し, システムの状態量やエネルギ 情報から状況に応じてそれらの制御器を自動的に切換 えることで, 任意の初期状態から振上げ, 倒立に至る非 線形制御を達成している. 振上げ・倒立振子は不安定で 非線形性が強く, 劣駆動システムであることから制御 手法の有効性を検証するためによく用いられる対象で ある.より不安定で非線形性の強いシステムへの適用 例題として, 二重倒立振子(6)や三重倒立振子(7)の安定化 制御問題, 二重倒立振子の振上げ・安定化制御問題 ${ }^{(8)(9)}$ に対して数多くの研究がなされている.

本研究では, 統合化 CNN 知的制御手法を拡張し, 非 線形性の強いシステムに対して有効な統合化知的制御 手法を提示する. その構造を図 2 に示す. 非線形系の大 きな特徵のひとつに平衡点が複数存在することが挙げ られる. そのようなシステムに対して, 各平衡点近傍に おいて局所的目的に基づいて設計された複数の制御器 を状況に応じて切換えるだけではなく, 制御目的に応 じて統合することで, システムの制御問題に対して有 効な制御入力を生成し, 少数の制御器および制御則に よって, 複数の制御問題への対処を試みる.

本研究では, 提案手法を 4 つの平衡点を有する二重倒 立振子の任意平衡点への移動 - 安定化制御に適用し, 提 案手法の具体的な設計方法を示す. 従来研究(10)では, 5 つの経路の移動・安定化制御に対して, 計 12 の制御器 と 11 の切換え則を必要としていたが, 本研究では, 提 案手法により，4つの制御器と状況に応じてそれらの切 換え・統合を行う 3 つの統合器によって, 9つの経路の 平衡点間移動・安定化制御を試みる. 数值計算と制御実 験により，提案手法の有効性を確認する.

\section{2. 二重倒立振子の任意平衡点への移動・安定化制御}

本研究では, 台車一振子システムを用いた二重倒立 振子の任意平衡点への移動・安定化制御を例題とする. 倒立振子の振上げ - 倒立制御問題は平衡点間の移動制 御問題であり, 安定平衡点の不安定化制御と不安定平

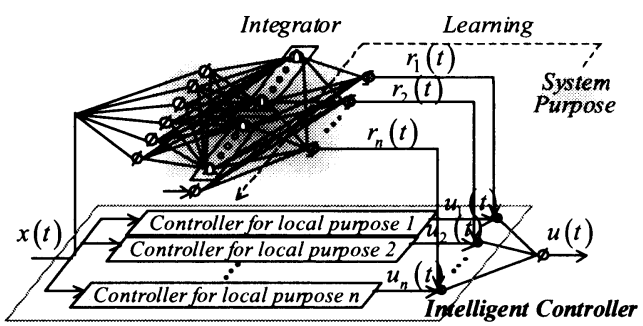

Fig.2 Concept of the Integrated Intelligent Control Method.
衡点の安定化制御という目的の異なる制御の切換えが 必要となる. また, 状況や条件に応じて制御器の切換え 条件が変わるため, 非線形性の強い問題となる. 図 3 に 示すように二重倒立振子は 1 つの安定平衡点と 3 つの不 安定平衡点を有するシステムである. 台車に取り付け られた振子を振子 1 , その先端部に取り付けられた振子 を振子 2 とする. 振子 1 , 振子 2 がともに安定な状態に ある安定平衡点を「Down-Down」, 振子 1 が安定状態で 振子 2 が倒立状態にある不安定平衡点を「Down-Up」, 振子 1 が倒立状態で振子 2 が安定な状態にある不安定平 衡点を「Up-Down」, 振子 1 , 振子 2 がともに倒立状態 にある不安定平衡点を「Up-Up」とする．図3に示すよ うに, ある平衡点から不安定平衡点への移動・安定化を 考えた場合，9つの移動経路が存在する．これまでに， 山北, 古田らによって回転式振子システムを用いて二 重倒立振子の平衡点間移動制御の研究が行われている. これらの研究では, 各移動経路に固有の制御問題に対 して, 複数の制御則と複数の切換え条件を準備し, いく つかのステップを経ることで移動・安定化制御が実現 されている(11) (14). 例えば, 移動経路 1 では制御則 6, 切換え則 $4^{(11)}$, 移動経路 9 では制御則 5 , 切換え則 $4^{(14)}$ を必要とし， 5 つの移動経路に対して，計 12 の制御則 と11の切換え則を用意しなければならない.

本研究では, 台車の移動幅や制御入力の制限などの 物理的な制約を考虑し, 知的制御を用いた包括的な設 計により，二重倒立振子の9つすべての平衡点間移動制 御を試みる. 具体的には, 各不安定平衡点における安定 化制御器と 1 つの振上げ制御器を設計し,これら4つの 制御器を制御目的に応じて切換え・統合する 3 つの統合 器により, 9つすべての平衡点間移動制御を達成する.

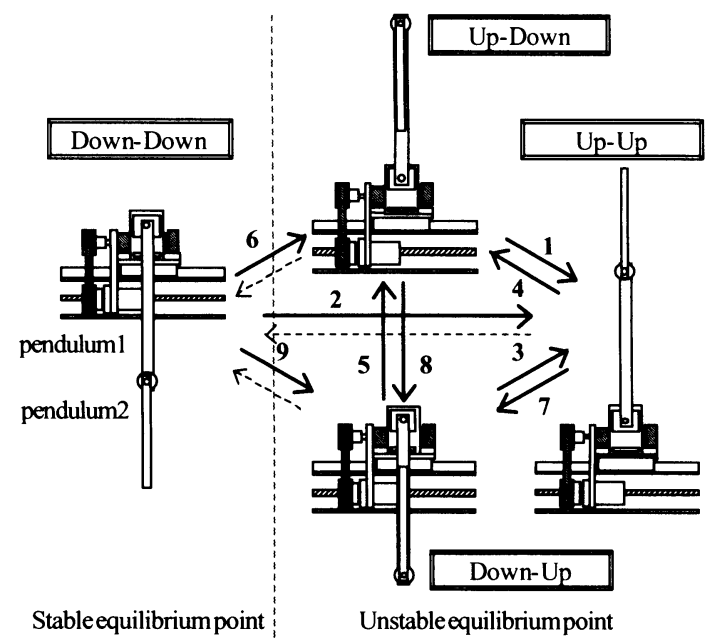

Fig.3 Stabilization Control to Arbitrary Equilibrium Point of Double Inverted Pendulum. 


\section{3. 二重倒立振子}

$3 \cdot 1$ 二重倒立振子モデル 台車一二重振子システ ムを図 4 に示す．台車にDCサーボモータが取り付けら れており, タイミングベルトを介してモータからロー タリーナットに回転運動を伝え，固定されたボールね じにより直線運動に変換される. 駆動系を有する台車 に，剛体棒による二重振子が振子角度を計测するため のロータリーエンコーダを介して接続されている．各 振子の回転軸はフリーである。水平なレール上を直線 的に左右に動ける台車を駆動することで, 台車上の二 重振子を制御する.

$3 \cdot 2$ 通動方程式台車, 振子 1 , 振子 2 に関する運 動方程式は次のようになる.

$$
\begin{aligned}
& \left(M_{c}+M_{p 1}+M_{p 2}\right) \ddot{x}+\left(M_{p 1} L_{1}+M_{p 2} L_{p 1}\right) \ddot{\theta}_{1} \cos \theta_{1} \\
& +M_{p 2} L_{2} \ddot{\theta}_{2} \cos \theta_{2}-\left(M_{p 1} L_{1}+M_{p 2} L_{p 1}\right) \dot{\theta}_{1}{ }^{2} \sin \theta_{1} \\
& -M_{p 2} L_{2} \dot{\theta}_{2}{ }^{2} \sin \theta_{2}+C_{c} \dot{x}=F-f_{c} \\
& \left(M_{p 1} L_{1}+M_{p 2} L_{p 1}\right) \ddot{x} \cos \theta_{1}+\left(M_{p 1} L_{1}{ }^{2}+M_{p 2} L_{p 1}{ }^{2}+I_{1}\right) \ddot{\theta}_{1} \\
& +M_{p 2} L_{p 1} L_{2} \ddot{\theta}_{2} \cos \left(\theta_{1}-\theta_{2}\right)-M_{p 2} L_{p 1} L_{2} \dot{\theta}_{2}{ }^{2} \sin \left(\theta_{1}-\theta_{2}\right) \\
& +\left(C_{p 1}+C_{p 2}\right) \dot{\theta}_{1}-C_{p 2} \dot{\theta}_{2}-\left(M_{p 1} L_{1}+M_{p 2} L_{p 1}\right) g \sin \theta_{1}=0 \\
& M_{p 2} L_{2} \ddot{x} \cos \theta_{2}+M_{p 2} L_{p 1} L_{2} \ddot{\theta}_{1} \cos \left(\theta_{1}-\theta_{2}\right)+\left(M_{p 2} L_{2}{ }^{2}+I_{2}\right) \ddot{\theta}_{2} \\
& -M_{p 2} L_{p 1} L_{2} \dot{\theta}_{1}^{2} \sin \left(\theta_{1}-\theta_{2}\right)-C_{p 2} \dot{\theta}_{1}+C_{p 2} \dot{\theta}_{2}-M_{p 2} L_{2} g \sin \theta_{2}=0
\end{aligned}
$$

ここで, 台車の変位を $x$, 倒立点を原点とする振子の 絶対角変位を $\theta_{1}, \theta_{2}$ とする. 制御入力であるモー夕の入 力電圧 $e$ と台車に作用する力 $F$ の関係は, 電圧方程式 $L i+K_{e} \dot{\eta}+R i=e$

と図 5 に示すモー夕の回転運動から台車の直線運動へ の関係より次式で表される。

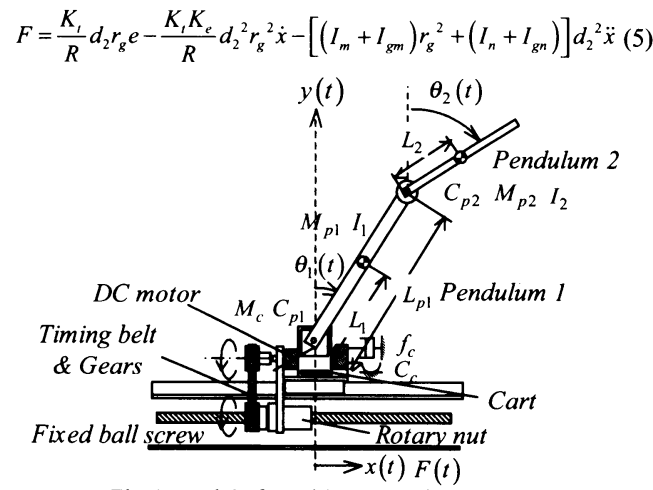

Fig.4 Model of Double Inverted Pendulum.

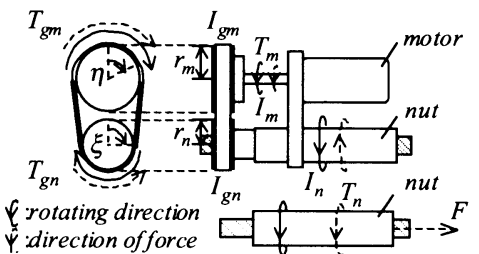

Fig.5 Translation from Torque of Motor to Control Force.
ここで, モータの回転角変位 $\eta$, モータの電流 $i$ とし た.これらの力学モデルは振子角度および台車ーレー ル間の摩擦などの非線形特性を有する．表 1 に本研究の 制御実験で使用した各装置の諸元を示す。台車の固体 摩擦 $f_{c}$ と動粘性摩擦定数 $C_{c}$, 振子の動粘性摩擦定数 $C_{p 1}, C_{p 2}$ は同定実験より算出したものである.

\section{4. 制御系設計}

二重倒立振子の任意平衡点への移動・安定化制御を 実現するために振上げ制御を行う制御器と各不安定平 衡点において安定化制御を行う制御器を設計する。ま た,これら目的の異なる制御器を目的に応じて切換え・ 統合を行う統合部を設計する.

4.1 安定化制御器の設計 各不安定平衡点近傍で 線形近似したシステムに対して, 二重振子の安定化を 行う線形な状態フィードバックコントローラを最適制 御理論より設計する。評価関数は

$$
J_{i}=\int_{0}^{\infty}\left[\mathbf{x}_{i}(t)^{T} Q_{i} \mathbf{x}_{i}(t)+u_{i}(t)^{T} R_{i} u_{i}(t)\right]
$$

である．各不安定平衡点における最適レギュレータの 重み $Q_{i}, R_{i}$, 得られた最適フィードバックベクトル $\mathbf{k}_{i}$, 状態量 $\mathbf{x}_{i}$, 各安定化制御器の制御入力 $u_{i}$ を以下に示す. Down-Up

$$
\begin{aligned}
& Q_{d u}=\operatorname{diag}\left(\begin{array}{llllll}
0 & 300 & 0 & 1 & 0 & 1
\end{array}\right), R_{d u}=1.0 \\
& \mathbf{k}_{d u}=\left[\begin{array}{lllllll}
-85.9198 & -17.3205 & 53.2593 & 493.0170 & -65.6931 & -616.7089
\end{array}\right] \\
& \mathbf{x}_{d u}=\left[\begin{array}{llllll}
\dot{x} & x & \dot{\theta}_{1 d} & \theta_{1 d} & \dot{\theta}_{2} & \theta_{2}
\end{array}\right]^{T} \\
& u_{d u}=-\mathbf{k}_{d u} \cdot \mathbf{x}_{d u}
\end{aligned}
$$

Table 1 Physical Parameters

\begin{tabular}{lll}
\hline Symbol & \multicolumn{1}{c}{ Quantity } & \multicolumn{2}{c}{ Value } \\
\hline$M_{\mathrm{c}}$ & mass of cart & $2.824 \mathrm{~kg}$ \\
$M_{\mathrm{pl}}$ & mass of pendulum 1 & $0.264 \mathrm{~kg}$ \\
$M_{\mathrm{p} 2}$ & mass of pendulum 2 & $0.054 \mathrm{~kg}$ \\
$L_{\mathrm{p} 1}$ & length of pendulum 1 & $0.321 \mathrm{~m}$ \\
$L_{\mathrm{p} 2}$ & length of pendulum 2 & \multicolumn{1}{c}{$0.194 \mathrm{~m}$} \\
$L_{1}$ & length from joint to a center of mass of pendulum 1 $0.215 \mathrm{~m}$ \\
$L_{2}$ & length from joint to a center of mass of pendulum $20.095 \mathrm{~m}$ \\
$I_{1}$ & moment of inertia of pendulum 1 & $3.22 \times 10^{-3} \mathrm{~kg} \cdot \mathrm{m}^{2}$ \\
$I_{2}$ & moment of inertia of pendulum 2 & $1.86 \times 10^{-4} \mathrm{~kg} \cdot \mathrm{m}^{2}$ \\
$I_{\mathrm{m}}$ & moment of inertia of motor axis & $6.96 \times 10^{-6} \mathrm{~kg} \cdot \mathrm{m}^{2}$ \\
$I_{\mathrm{n}}$ & moment of inertia of rotary nut & $4.80 \times 10^{-5} \mathrm{~kg} \cdot \mathrm{m}^{2}$ \\
$I_{\mathrm{gm}}$ & moment of inertia of gear pulley(motor) & $2.20 \times 10^{-6} \mathrm{~kg} \cdot \mathrm{m}^{2}$ \\
$I_{\mathrm{gn}}$ & moment of inertia of gear pulley(nut) & $2.56 \times 10^{-5} \mathrm{~kg} \cdot \mathrm{m}^{2}$ \\
$f_{\mathrm{c}}$ & coulomb friction of cart & $45.0 \mathrm{~kg} \cdot \mathrm{m} / \mathrm{s}$ \\
$C_{\mathrm{c}}$ & damping coefficient of cart & $177 \mathrm{~kg} / \mathrm{s}$ \\
$C_{\mathrm{p} 1}$ & damping coefficient of pendulm 1 & $2.67 \times 10^{-3} \mathrm{~kg} \cdot \mathrm{m} / \mathrm{s}^{2}$ \\
$C_{\mathrm{p} 2}$ & damping coefficient of pendulum2 & $1.02 \times 10^{-4} \mathrm{~kg} \cdot \mathrm{m} / \mathrm{s}^{2}$ \\
$l^{2}$ & lead of ball screw & $1.6 \times 10^{-2} \mathrm{~m} / \mathrm{round}$ \\
$d_{2}$ & transfer coefficient from torque to force & $1.02 \times 10^{-4} \mathrm{~kg} \cdot \mathrm{m} / \mathrm{s}^{2}$ \\
$L$ & inductance of motor & $6.20 \times 10^{-4} \mathrm{H}$ \\
$R$ & resistance of motor & $2.07 \mathrm{~W}$ \\
$K_{\mathrm{e}}$ & induced voltage constant of motor & $5.25 \times 10^{-2} \mathrm{~N} \cdot \mathrm{s} / \mathrm{A}$ \\
\hline & &
\end{tabular}




\section{Up-Down}

$Q_{u d}=\operatorname{diag}\left(\begin{array}{llllll}0 & 300 & 0 & 50000 & 0 & 500\end{array}\right), R_{u d}=1.0$

$\mathbf{k}_{u d}=\left[\begin{array}{llllll}-92.3226 & -17.3205 & -32.4339 & -313.7022 & -0.2756 & 14.3866\end{array}\right]$

$\mathbf{x}_{u d}=\left[\begin{array}{llllll}\dot{x} & x & \dot{\theta}_{1} & \theta_{1} & \dot{\theta}_{2 d} & \theta_{2 d}\end{array}\right]^{T}$

$u_{u d}=-\mathbf{k}_{u d} \cdot \mathbf{x}_{u d}$

$\underline{U p-U p}$

$Q_{u u}=\operatorname{diag}\left(\begin{array}{llllll}0 & 300 & 0 & 1 & 0 & 1\end{array}\right), R_{u u}=1.0$

$\mathbf{k}_{u u}=\left[\begin{array}{llllll}10.2913 & 17.3205 & 14.0202 & -353.1186 & 64.2297 & 607.4820\end{array}\right]$

$\mathbf{x}_{u u}=\left[\begin{array}{llllll}\dot{x} & x & \dot{\theta}_{1} & \theta_{1} & \dot{\theta}_{2} & \theta_{2}\end{array}\right]^{T}$

$u_{u u}=-\mathbf{k}_{u u} \cdot \mathbf{x}_{u u}$

図 6 に各平衡点において垂直方向を基準とした振子 角度を定義し, 設計した各安定化制御器の可安定化領 域を示す.ただし, 制御入力の上下限は $\pm 25.0 \mathrm{~V}$ とし, 初 期状態において振子角度以外の状態量は 0 とする.

$4 \cdot 2$ 振上げ制御器の設計不安定平衡点のなかで 最もエネルギーが大きい Up-Up の状態と同じだけのエ ネルギーを振子に与える振上げ制御器を用いることに より, どの状態においても各不安定平衡点に移動する ために必要なエネルギーを振子に与えることが可能と なる. 以上から，本研究では振上げ制御器はUp-Upへ
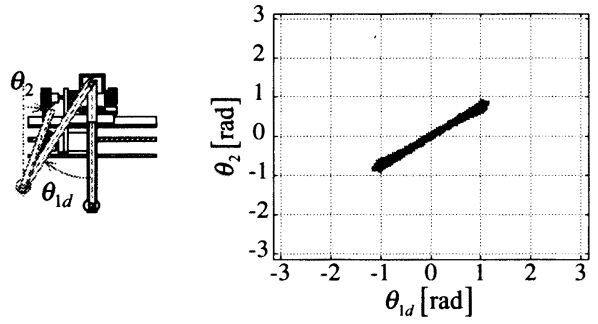

(a) Down-Up
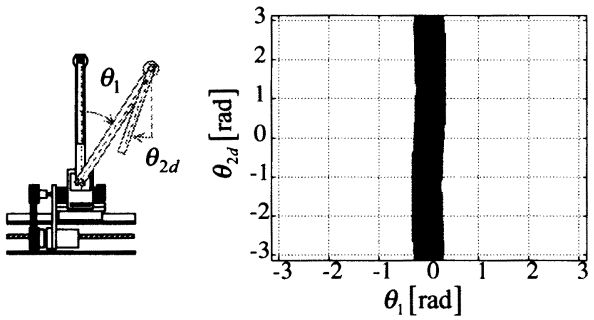

(b) Up-Down
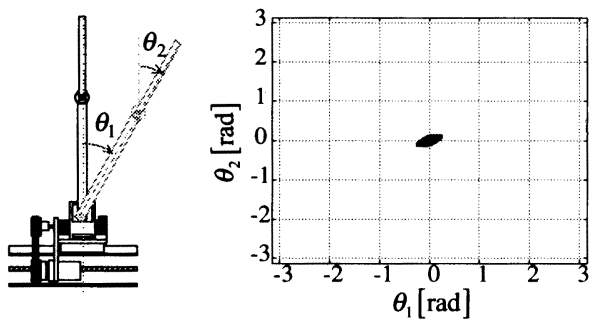

(c) Up-Up

Fig.6 Stabilized region of controller.
振り上げるものを 1 つだけ用いることにする．振子の エネルギーに基づき，台車に一定の加速度を与えるこ とにより振子を振り上げる振上げ制御器が提案されて いる(15)(16). しかし, 本研究の制御対象は制御入力の上 下限が小さく，システムの動摩擦が大きいため，制御入 力の飽和やシステムの不確定要素等の影響により, 台 車の加速度を所望の值に制御するのは困難である。そ こで，エネルギーに基づいた振上げ制御器の設計法を 参考にして，物理的制約や不確定要素の影響を考虑し た振上げ制御器を提案する. 台車の加速度が 0 の場合, $\mathrm{Up}-\mathrm{Up}$ 状態を基準とした振子のエネルギー $E$ は,

$$
\begin{aligned}
E & =\frac{1}{2}\left(I_{1}+M_{p 1} L_{1}^{2}+M_{p 2} L_{p 1}{ }^{2}\right) \dot{\theta}_{1}^{2}+M_{p 2} L_{p 1} L_{2} \dot{\theta}_{1} \dot{\theta}_{2} \cos \left(\theta_{1}-\theta_{2}\right) \\
& +\frac{1}{2}\left(I_{2}+M_{p 2} L_{2}^{2}\right) \dot{\theta}_{2}^{2}+M_{p 1} L_{1} g\left(\cos \theta_{1}-1\right) \\
& +M_{p 2} g\left[L_{p 1}\left(\cos \theta_{1}-1\right)+L_{2}\left(\cos \theta_{2}-1\right)\right]
\end{aligned}
$$

となる. さらに, 振子のエネルギーの時間に関する微分 は，台車の加速度 $a$ を用いることによって

$$
\frac{d E}{d t}=-\left[\left(M_{p 1} L_{1}+M_{p 2} L_{p 1}\right) \dot{\theta}_{1} \cos \theta_{1}+M_{p 2} L_{2} \dot{\theta}_{2} \cos \theta_{2}\right] a
$$

となる(17). (11) 式より, 台車の加速度が一定であるな ら，振子のエネルギーの変化率が大きいのは振子が真 下で垂れ下がった状態である．また，振子のエネルギー 変化率が小さいのは振子が水平方向付近にあるときで ある。したがって，振子が垂れ下がった付近で大きな加 速度を与えることができれば効率の良い振り上げを行 うことが可能となる。そこで，以下のような振上げ制御 器を提案する.

$$
\begin{gathered}
u_{s w g}=\alpha \cdot\left\{\frac{2}{1+\exp \left[-\gamma \cdot(E-\beta) \cdot \operatorname{sgn}_{x}\left(\theta_{1}\right)\right]}-1\right\} \\
\operatorname{sgn}_{x}\left(\sin \theta_{1}\right)=\left\{\begin{array}{lll}
1 & \sin \theta_{1}>0 & \ldots \\
-1 & \sin \theta_{1}<0 & \ldots \\
1 & \sin \theta_{1}=0, x \geq 0 & \ldots \\
-1 & \sin \theta_{1}=0, x<0
\end{array}\right.
\end{gathered}
$$

ここで, $\alpha$ は台車移動幅を考虑するため, $\beta$ はシステム の摩擦損失を補償するため, $\gamma$ はチャタリング防止のた めに用いたシグモイド関数のパラメータである。本研 究では,これらのパラメータはシミュレーションによ り試行錯誤的に決定した， $\alpha$ は台車移動制限幅かつ振上 げ時間を考慮し $\alpha=16, \beta$ は Up-Up 付近に振子のエネル ギを保つことができるものとして $\beta=0.15$ とした。ま た, $\gamma$ は振上げ制御時にチャタリングが発生しない最大 值付近として $\gamma=20.0$ とした. (13-c), (13-d)式は統合器 設計時に台車一振子システムの対称性を利用すること から，二重振子が Down-Down あるいはUp-Up で静止し ている場合には，台車位置をレール中央部に戻すよう な制御入力を与えるように設定した条件式である.

$4 \cdot 3$ 統合器の設計 二重倒立振子の任意平衡点へ 
の移動・安定化制御を実現するためには, 各平衡点で設 計した目的の異なる複数の制御器の切換え・統合が必 要となる.この制御器の切換え・統合には強い非線形性 が必要となる. また, 台車一振子システムでは, 物理的 制約, 特に台車の移動幅, 入力の上下限といった制約の もとで制御目的を達成しなければならない，このよう な条件下において, 各制御器の切換え・統合条件を IFTHEN 文や数式によって明示的に表現することは困難で ある. 本研究では, 統合化 $\mathrm{CNN}$ 知的制御手法を拡張し, 統合器により複数の制御器の切換え・統合を行う. 統合 器としてラジアル基底関数ニューラルネットワーク (RBFNN)を用い, 各パラメータは遺伝的アルゴリズム （GA）による学習によって獲得する. RBFNNは, ニュー ラルネットワークよりも少ない中間層のユニット数に よって局所的な領域分けを行うことが可能である(18).

本研究では 3 つの安定化制御器, 1 つの振上げ制御器 と1つの統合器によって, 各平衡点から1つの不安定平 衡点に至る移動・安定化制御を実現する. その構造を図 7 に示す。二重倒立振子は 3 つの不安定平衡点を有する ことから，3つの統合器を設計する. ただし, 統合器で あるRBFNNの構造は不変なものとし, 目的を反映した 適応度により目的に応じた統合器の獲得を試みる. 統 合器として用いる RBFNN の構造を図 8 に示す。入力は 台車一振子システムの状態変数である $\dot{x}, x, \dot{\theta}_{1}, \theta_{1}, \dot{\theta}_{2}, \theta_{2}$ を 正規化した情報とした. 本研究では, $\dot{x}_{c}=0.7, x_{c}=0.4$, $\dot{\theta}_{1 c}=15.0, \theta_{1 c}=3.2, \dot{\theta}_{2 c}=30.0, \theta_{2 c}=3.2$ とした. 中間層のラ ジアル基底関数は， $n$ 個の入力に対して次式で表される ものを用いた.

$$
\varphi(\mathbf{x})=\prod_{i=1}^{n} \exp \left\{-\frac{\left(x_{i}-a_{i}\right)^{2}}{b_{i}^{2}}\right\}
$$

台車一振子システムは対称性を有する，そこで, 統合 器の構造は台車一振子システムの対称性を利用したも のとする. 具体的には, 中間層の $j$ 番目の $i$ 入力に対す るラジアル基底関数のパラメータを $a_{i j}, b_{i j}$, 中間層の $j$

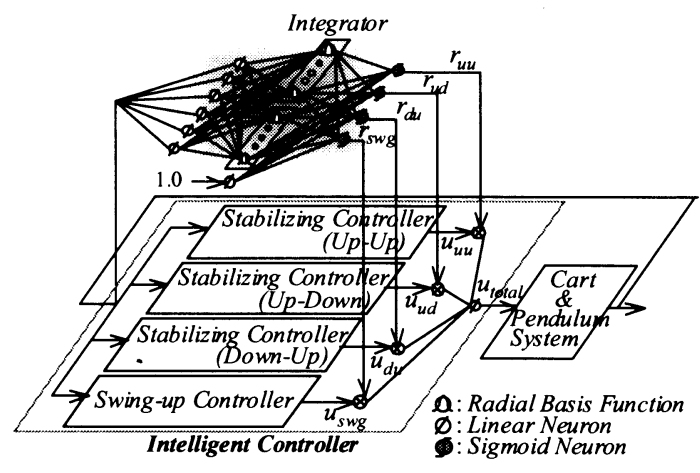

Fig.7 Structure of proposed method.
番目のユニットと出力層の $k$ 番目のユニットの間の重み 値を $w_{j k}$ としたとき, 次の関倸を満たすようにする. た だし，中間層のユニット数は $2 m+1$ とする.

$$
\begin{array}{ll}
a_{i(m+j)}=-a_{i j} & (j=1,2, \cdots, m) . \\
b_{i(m+j)}=b_{i j} & (j=1,2, \cdots, m) . \\
w_{(m+j) k}=w_{j k} & (j=1,2, \cdots, m)
\end{array}
$$

統合器への入カベクトルを $\mathbf{x}$, 統合器の出カベクトル を $\mathbf{r}(\mathbf{x})$ とすると,

$$
\mathbf{r}(\mathbf{x})=\mathbf{r}(-\mathbf{x})
$$

となることから,

$u(\mathbf{x})=-u(-\mathbf{x})$

の関係を得る。したがって，RBFNNによって統合され た制御器は対称性を有するといえる. 出力層は次式で 示すシグモイド関数を用いた.

$$
y=\frac{1}{1+\exp (-200 x)}
$$

シグモイド関数によって, 0 から 1 までの連続的な值 をとることが可能となり，0 または 1 の領域分けによる 制御器の切換えだけではなく, 制御器のゲイン調節や, 複数の制御器の統合を行うことが期待される. 統合器 は 4 つの出力値をもち, 統合器の出力と各不安定平衡点 における安定化制御器の出力, 振上げ制御器の出力か ら最終的な制御入力 $u$ は次式によって決定される.

$$
u=r_{u u} \cdot u_{u u}+r_{u d} \cdot u_{u d}+r_{d u} \cdot u_{d u}+r_{s w g} \cdot u_{s w g}
$$

RBFNN のパラメータは GA を用いた学習により獲得 した. 1 世代の個体数は 50 とし, 移動目標平衡点以外 の平衡点を初期状態とし, 各初期状態からのシミュ レーションを行い，下記に示す適応度をそれぞれ求め, 個々の適応度の総和を最終的な適応度とする.

$$
\begin{aligned}
& \text { fitness }=\frac{h(x)}{n} \cdot \sum_{i=0}^{n}\left(\frac{1}{10 \cdot p_{1}{ }^{2}+10 \cdot p_{2}{ }^{2}+1}\right) \\
& h(x)=\left\{\begin{array}{cc}
1 & |x| \leq 0.4 \mathrm{~m} \\
0.1 & |x|>0.4 \mathrm{~m}
\end{array}\right.
\end{aligned}
$$

ここで, $n=t_{f} / \Delta t$ である. $t_{f}$ はシミュレーション時間, $\Delta t$ はサンプリング時間を表し, それぞれ $t_{f}=10 \mathrm{~s}, \Delta t=5 \mathrm{~ms}$ とした. $h(x)$ は台車移動制限に対するペナルティ関数で ある. $p_{1}, p_{2}$ は制御目的が達成されたときに 0 となるよう な変数とする. つまり, 各平衡点から Up-Up に至る移

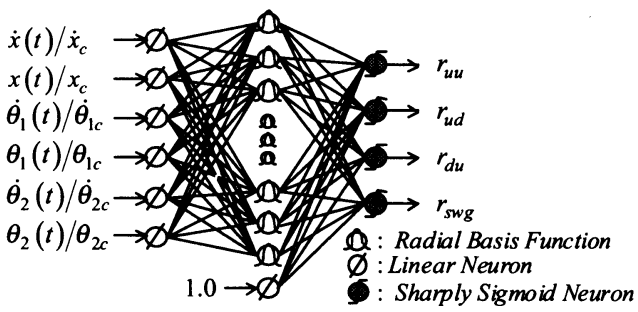
Fig.8 Integrator Neural Network. 
動・安定化制御を行うための統合器の学習には $\left(p_{1}, p_{2}\right)=\left(\theta_{1}, \theta_{2}\right)$ を用いる. Up-Down, Down-Up を制御目 標とした場合には，それぞれ $\left(p_{1}, p_{2}\right)=\left(\theta_{1}, \theta_{2 d}\right)$, $\left(p_{1}, p_{2}\right)=\left(\theta_{1 d}, \theta_{2}\right)$ とする. 個体の選択には, 適応度比例と 1 個体のエリート保存を行い, 交叉には一様交叉を用い, 交叉確率は 0.6 とした. 突然変異は各染色体に対して 0.1 の確率で行った。 また, 初期集団, 突然変異におい てRBFNN の各パラメータの範囲は

$-1 \leq a_{i j} \leq 1$.

$0.01 \leq b_{i j} \leq 1$

$-1 \leq w_{j k} \leq 1$

とし, 各パラメータの変動は共に 0.01 刻みとした.

\section{5. 数值計算}

$5 \cdot 1$ 任意平衡点への移動・安定化制御提案手法 の有効性を確認するために数值計算を行った. 設計し た振上げ制御器と 3 つの安定化制御器を切換え・統合 し, 任意の不安定平衡点への移動・安定化を行なう. 数 值計算結果は上から順に台車位置, 振子 1 の角度, 振子 2 の角度, 制御入力, Up-Up, Up-Down, Down-Up 安定 化制御器, 振上げ制御器に対する統合器からの重み付 け係数の時刻歴を示す. Down-Upへの移動を目的とす る統合器を用いた場合の数值計算結果を図 9 に示す. ど の初期状態からも目標状態に達成するための特殊な制

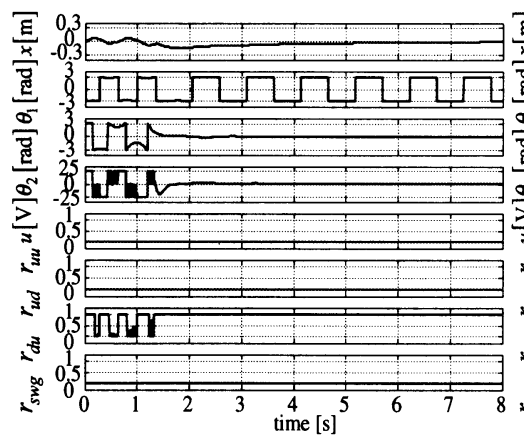

(a) Down-Down

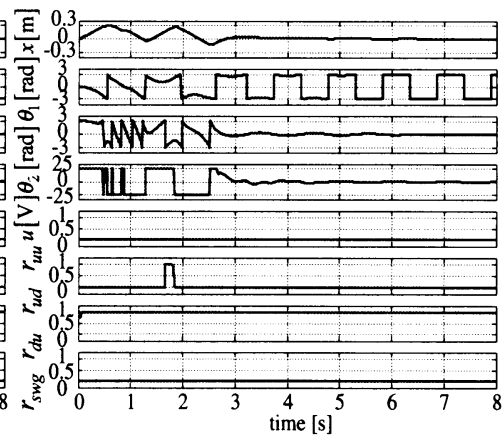

(b) Up-Down

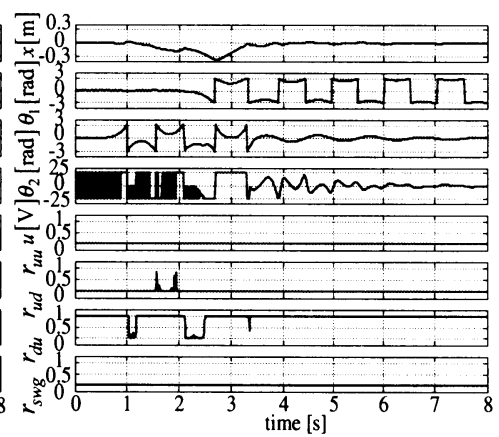

(c) Up-Up

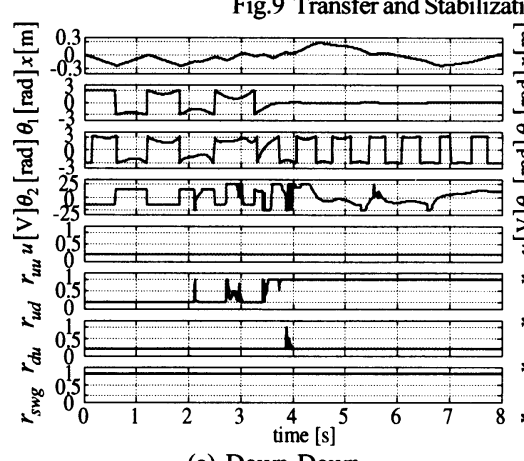

(a) Down-Down

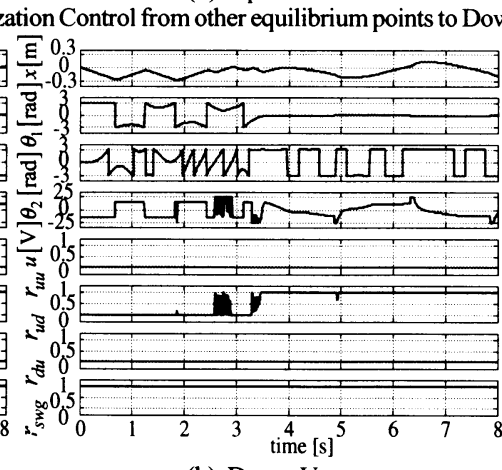

(b) Down-Up

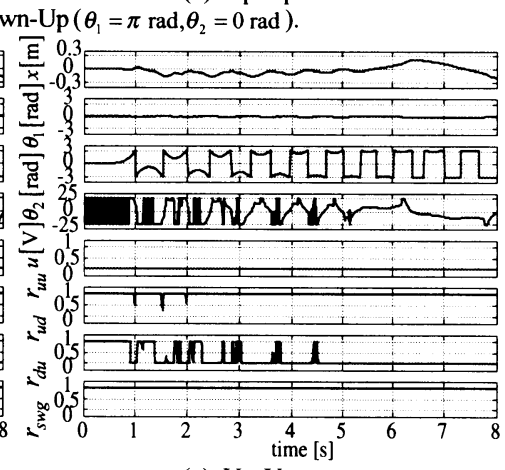

(c) Up-Up

Fig.10 Transfer and Stabilization Control from other equilibrium points to Up-Down $\left(\theta_{1}=0 \mathrm{rad}, \theta_{2}=\pi \mathrm{rad}\right)$.

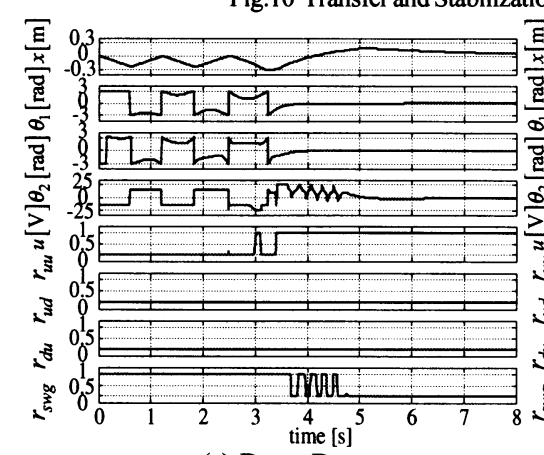

(a) Down-Down

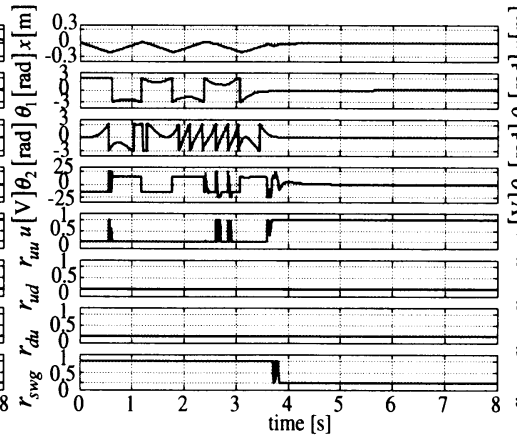

(b) Down-Up

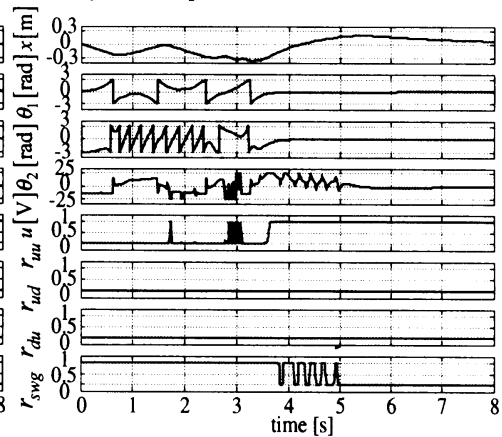

(c) Up-Down

Fig.11 Transfer and Stabilization Control from other equilibrium points to $U p-U p\left(\theta_{1}=0 \mathrm{rad}, \theta_{2}=0 \mathrm{rad}\right)$. 
御則や切換え則を制御系が有しているわけではないが, 状況に応じて 4 つの制御器を切換え・統合することで Down-Up状態に至り, 安定化制御を達成していることが わかる. Up-Down への移動を目的とする統合器を用い た場合の数値計算結果を図 10 に示す。振上げ制御器と Up-Down 安定化制御器の切換え・統合に加えて, 状況に 応じて Down-Up 安定化制御器も用いることで制御目的 を達成している. Up-Upへの移動を目的とする統合器 を用いた場合の数值計算結果を図 11 に示す.どの初期 状態からも振上げ制御器と安定化制御器を状況に応じ て切換え・統合することでおよそ 5 秒で移動・安定化制 御を達成している. 数值計算結果より, 提案手法による 知的制御を用いた包括的な制御系設計によって，9つす ベての不安定平衡点への移動・安定化制御が可能であ ることを確認した。 また, 図 9, 図 10 , 図 11 の(b), (c) に示すように, 不安定平衡点間の移動・安定化制御につ いても, 振上げ制御器とそれぞれの平衡点での安定化 制御器を切換え・統合することで振上げを実現し, その 後安定化を達成している結果が得られた.

$5 \cdot 2$ エネルギー变化を考虑した知的制御手法 二重 倒立振子の平衡点間移動・安定化制御において, Up-Up への移動・安定化を目的としただけでは, 図 11 (c)に示 すように, 1 度振子 1 を倒した後, 振上げ・安定化を行 う制御が移動時間が短く, 適応度も高い.しかし,これ

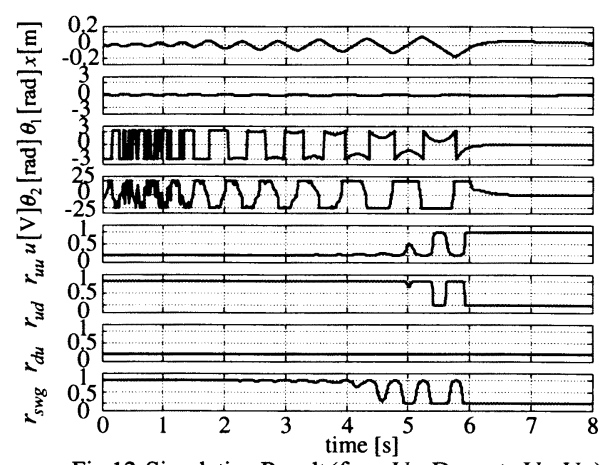

Fig.12 Simulation Result (from Up-Down to Up-Up)

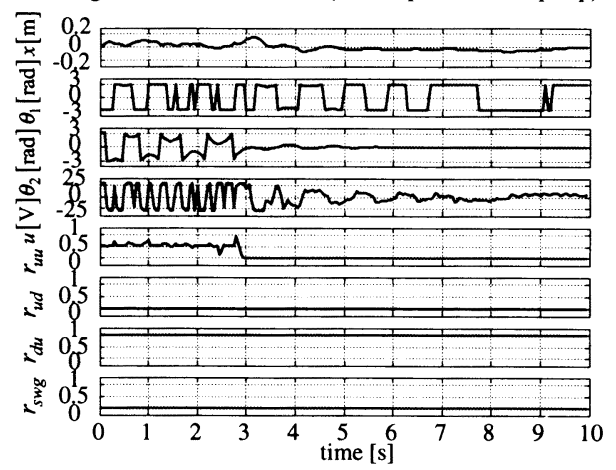

Fig.13 Experimental Result (from Down-Down to Down-Up).
はエネルギー効率が悪いと考えられる. そこで, UpDownからUp-Upへの移動制御において, エネルギーの 変化が小さい制御を試みる. 以下に示すエネルギー変 化を考慮した適応度により目的を達成する統合器の学 習を行った。

$$
\begin{aligned}
& \text { fitness }=\frac{h(x) \cdot k\left(\theta_{1}\right)}{n} \cdot \sum_{i=0}^{n}\left(\frac{1}{10 \cdot p_{1}{ }^{2}+10 \cdot p_{2}{ }^{2}+1}\right) \\
& k\left(\theta_{1}\right)=\left\{\begin{array}{cc}
1 & \left|\theta_{1}\right| \leq 0.2 \mathrm{rad} \\
0.01 & \left|\theta_{1}\right|>0.2 \mathrm{rad}
\end{array}\right.
\end{aligned}
$$

振子 1 の角度に関するペナルティ関数 $k\left(\theta_{1}\right)$ を適応度に 導入することにより，エネルギー変化の小さな移動制 御が期待される. 設計した制御器を用いて行ったUpDownからUp-Upへの移動・安定化制御の数値計算結果 を図 12 に示す. 振上げ制御器, Up-Down 安定化制御器, Up-Up 安定化制御器を状況に応じて切換え・統合するこ とで, 振子が倒れることなく, Up-Down からUp-Upへ の移動・安定化制御を達成した.

\section{6. 制御実験}

提案手法の有効性を確認するために制御実験を行っ た.このとき, 台車移動制限は $\pm 0.40 \mathrm{~m}$ とし, 初期状態 において $\dot{x}=x=\dot{\theta}_{1}=\dot{\theta}_{2}=0.0$ とする. また, 制御入力の上下 限を $\pm 25.0 \mathrm{~V}$ とし, その範囲外では一定値とした. 制御 実験結果は数値計算結果と同様の順番で時刻歴を示す.

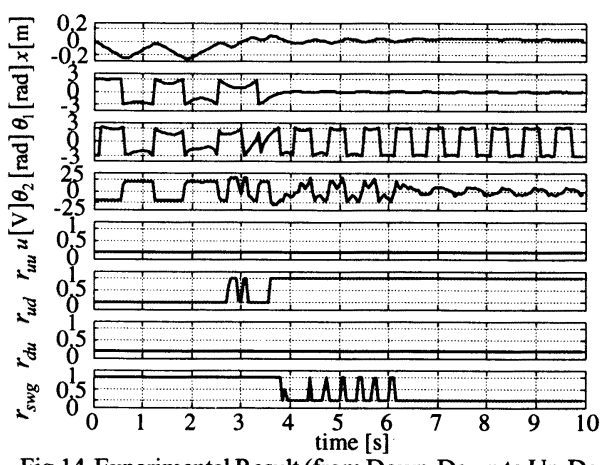

Fig.14 Experimental Result (from Down-Down to Up-Down).

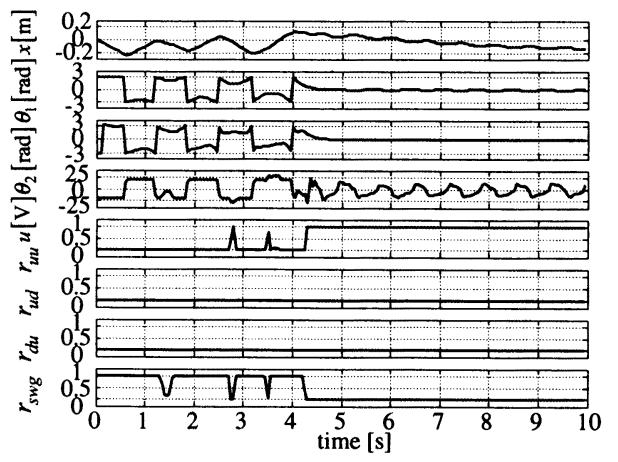

Fig.15 Experimental Result (from Down-Down to Up-Up). 


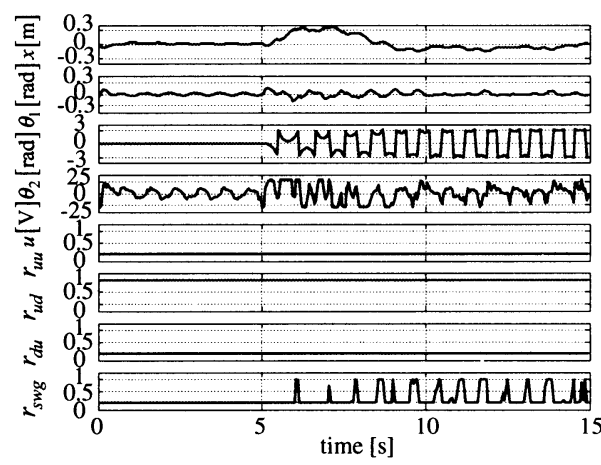

Fig.16 Experimental Result (from Up-Up to Up-Down).

図 13 にDown-Down から Down-Up, 図 14 にDown-Down からUp-Down, 図 15 に Down-Down からUp-Up, 図 16 にUp-Up からUp-Down, 図 17 にp-Down からUp-Up への移動・安定化制御実験の結果を示す. Up-Down か らUp-Upへの移動・安定化制御は上述したエネルギー 変化を考慮した学習による統合器を用いた。制御実験 結果より, 摩擦などの不確定要素の影響が大きいため, 数値計算結果とは異なるが, 状況に応じた制御器の切 換え・統合が行われることによって, 目標とする不安定 平衡点への移動・安定化が可能であることを実験的に 示した.

\section{7. 結論}

本研究では, 統合化 $\mathrm{CNN}$ 知的制御手法を挔張し, 複 数制御器を状況に応じて切換え・統合する統合器を有 する統合化知的制御手法を提案し, 少数の制御器およ び制御則によって, 複数の制御問題への対処を試みた. 提案手法の有効性を検証するために, 二重倒立振子の 任意平衡点への移動・安定化制御問題に適用した. 従来 手法では, 5 つの移動経路に対して, 計 12 の制御則と 11 の切換え則を必要とした。提案した統合化知的制御 手法では, 4 つの制御器と状況に応じてそれらの切換 え・統合を行う 3 つの統合器によって，9つの平衡点間 移動・安定化制御が可能であることを数值計算によっ て確認した. また, 提案する手法により目標とする不安 定平衡点への移動・安定化が可能であることを実験的 に示した. 以上の結果, 知的制御を用いた包括的な設計 法により，局所的な目的に基づいて設計された制御器 を状況に応じて切換えるだけではなく, 制御目的に応 じて統合することで, システムの機能の拡張が容易に 行える一手法を提示した.

\section{文献}

(1) Kidoshi, H. and Yoshida, K., Intelligent Control Method Using Cubic Neural Network with Multi-Levels of Information Abstraction, IEEE International Conference on Neural Network, Vol.5, (1995), 2326-2331.

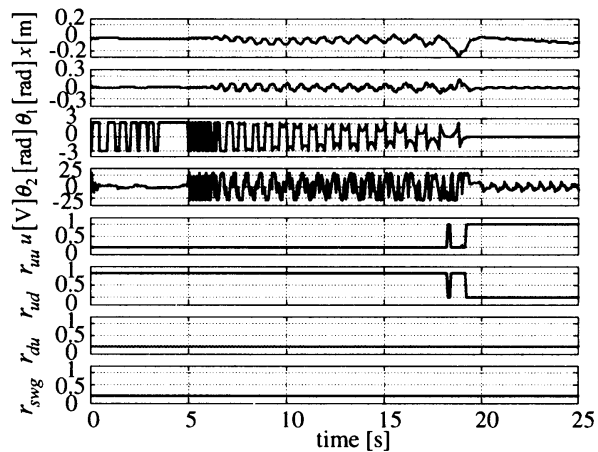

Fig.17 Experimental Result (from Up-Down to Up-Up).

(2) 吉田和夫, キューピックニューラルネットワークを用いた知的制 御, システム/制御／情報, 43-7, (1999), 328-336.

(3) Yoshida, K. and Hatano, K., Intelligent Control Using Cubic Neural Network for Swinging up and Stabilizing Pendulum, J. JSME, 43-3, (2000), 612-617.

(4) 高橋正樹・吉田和夫, キュービックニューラルネットワークを用 いた二重振子の振上げ・倒立知的制御, 機論, 68-676,C(2002), 36363643.

(5) Takahashi, M. and Yoshida, K., Intelligent Failure-Proof Control Using Cubic Neural Network (Application to Swinging up and Stabilizing Double Pendulum), The 6th International Conference on Motion and Vibration Control, 02-201, (2002), 265-270.

(6) Furuta, K., Kajiwara, H. and Kosuge, K., Digital Control of a Double Inverted Pendulum on an Inclined Rail, J. Control, 32-5, (1980), 907-924.

(7) Furuta, K., Ochiai, T. and Ono, N., Attitude control of a triple inverted pendulum, J. Control, 39-6, (1984), 1351-1365.

(8) Rubi, J., Rubio, A. and Avello, A., Swing-up Control Problem for a Selferecting Double Inverted Pendulum, Proc. IEE, Control Theory and Applications, 149-2, (2002), 169-175.

(9) Zhong, W. and Rock, H., Energy and Passivity Based Control of the Double Inverted Pendulum on a Cart, Proc. The 2001 IEEE International Conference on Control Applications, (2001), 896-901.

(10)Yamakita, M. and Furuta, K., Torward robust state transfer control of TITech double pendulum, The Astrom Symposium on Control, (1999), 73-96.

(11)Yamakita, M., Iwashiro, M., Sugahara, Y. and Funuta, K., Robust Swing Up Control of Double Pendulum, Proc. The American Control Conference, (1995), 290-295.

(12)野中詿一郎·山北昌毅・古田勝久, 二重倒立振子の振り上げ制御 , 計測自動制御学会学術講演会予稿集, (1992), 429-430.

(13) Yamakita, M., Nonaka, K. and Furuta, K., Swing up control of a double pendulum, Proc. The American Control Conference, (1993), 2229-2233.

(14) 菅原能生・山北昌毅・古田勝久, 二重振子の平衡点間推移制御, 計測自動制御学会学術陆演会予稿集, (1993), 241-242.

(15) Wiklund, M., Kristenson, A. and Astrom, K. J., A New Strategy For Swinging Up An Inverted Pendulum, Proc. The 12th Triennial World Congress of the International Federation of Automatic Control, (1993), 757-760.

(16)Astrom, K. J. and Furuta, K., Swinging Up a Pendulum by Energy Control, Automatica, 36-2, (2000), 287-295

(17)Astrom, K. J., Furuta, K., Iwashiro, M. and Hoshino, T., Energy Based Strategies for Swinging Up a Double Pendulum, Proc. The 14th World Congress International Federation of Automatic Control, 14, (1999), 283-288.

(18) 丸山稔, Radial Basis Functionsを用いた学習ネットワークーニュー ロコンピューティングに対する新しいアプローチー, システム／ 制御／情報, 36-5, (1992), 322-329. 